\title{
THE PROFILE OF STATE ISLAMIC PRIMARY SCHOOL TEACHER EDUCATION IN PALANGKA RAYA
}

\author{
Rahmad \\ Primary School Teacher Education Department, \\ Institut Agama Islam Negeri Palangkaraya, Indonesia \\ Email: $\underline{\text { rahmad@iain-palangkaraya.ac.id }}$ \\ Website: \\ https://jurnal.uinantasari.ac.id/index.php/adzka \\ Received: 30 January 2021; Accepted: 30 June 2021; Published: 13 July 2021 \\ DOI: $\underline{10.18952 / a l a d z k a p g m i . v 11 i 1.4438}$
}

\begin{abstract}
ABSTRACK
Teacher is a professional position or profession. As a teacher, one of the competencies needed is professional competence. This study aims to look at the profile or educational background of MI teachers in the city of Palangka Raya. This research is important for the PGMI Study Program because it is the initial data for mapping the educational background of teachers in MIN Palangka Raya so that it can be the initial basis for collaboration between the Ministry of Religion of Central Kalimantan Province and PGMI Study Program related to increasing qualifications or procurement of educators in MIN Palangka Raya. This study uses a qualitative approach with data collection techniques through interviews with the head of the state Islamic madrasah in Palangka Raya. The results obtained are that the latest education is appropriate with the work as a class teacher obtained a percentage of $36.36 \%$ of class teachers with educational backgrounds or the latest bachelor's degree in Islamic primary school or elementary school teacher education.
\end{abstract}

Keywords : state Islamic primary school; classroom teacher; educational background

\section{INTRODUCTION}

Profession is an activity that requires expertise from someone, or in other words, it cannot be done by someone without special preparation in its implementation. These skills are obtained after undergoing or before carrying out their profession (Laelasari, 2013, p. 153). Teachers are professional educators, in the juridical aspect (Ministry of National Education, nd). When doing a profession, of course, it must be supported through various experiences and theories that have been passed and learned. To do work professionally will rely on theory, practice and experience gained. This is in contrast to non-professionals who only rely on their practice and experience (Yamin, 2006, p. 21). A professional teacher certainly becomes a profession that is cultivated well through the fields of knowledge, ability, and high motivation in carrying out its work.

Education Standards (Regulation of the Government of the Republic of Indonesia Number 19 of 2005 concerning National Education Standards, 2005) states that academic requirements such as degrees, backgrounds in education must be appropriate or linear with the subjects being taught. The Islamic primary school or elementary school teacher must have an S1 PGMI/PGSD certificate in a university under the Ministry of Religion or the Ministry of Research, Technology, and Higher Education of the Republic of Indonesia. In (Law No. 20 of 2003 concerning the National Education System, 2003) it is stated that four competencies must be possessed by teachers, one of which is professional competence. So that the position of a teacher must have good academic qualifications and appropriate with the subjects being taught, such as being a classroom teacher at Islamic primary school is a graduate of PGMI, or Islamic primary school teachers should have appropriate academic requirements. 
The position of the teacher is so respectable in the teachings of Islam. The teacher gets a position as uswah, a pious person who is always required to do good deeds as a form of applying the height of his knowledge who is also very responsible during learning or after (Naim, 2009, p. 5). Regarding the problem of teacher education background with the subjects taught, the Ministry of Education and Culture has issued 18 (Eighteen) Education and Culture development problems (Ministry of Education and Culture, 2015). Several points of problems that can be described related to the quality of teachers, among others, are that quality compulsory education can be said to be still not optimal. An indicator of this, for example, is that the management of teacher education has not been maximized.

Ana Maria Petrescu said that the development of the teaching profession is an increase in the quality of teacher competence. (Putri \& Imaniyati, 2017, p. 94). Based on the applicable regulations both through Law no. 14 or PP No. 19 of 2005 mentions the qualifications of teachers are required to have an educational background appropriate to elementary school or Islamic primary school qualification or other education.

Education has a positive and significant effect on employee performance so that the hypothesis that it is suspected that education affects performance is acceptable. (Kapahang, Kojo, \& Uhing, 2014, ph 511). The results of Suwandi's research in 2016 stated that the problem of teacher management in Indonesia leads to the procurement of teachers who have three main problems such as teacher qualifications that are not following the formations offered, needs that are also not by existing formations, and the transfer process that does not pay attention to qualifications. teachers (Triwiyanto, Kusumaningrum, \& Gunawan, 2017).

Based on the description described above, the incompatibility of the teacher's background can indeed be a problem. And based on this phenomenon, this study seeks to create a profile of the educational background of state Islamic primary school teachers in Palangka Raya.

\section{RESEARCH METHODS}

This study used a qualitative descriptive method. This method is expected to be able to fully and thoroughly describe the observations made at the Ibtidaiyah Madrasah in Palangka Raya City. This observation was also carried out by interviewing the head of the school regarding problems related to the implementation of education in Islamic primary schools, interviews would also try to look deeply into matters related to efforts to improve the competence of Islamic primary school teachers carried out by the school. In addition to interviews with the principals and vice-principals of Islamic primary school in Palangka Raya, a check of data obtained through the school's monthly routine reports related to information such as the condition of one of the teachers was also carried out. The number of Islamic primary schools observed are all state Islamic primary schools in Palangka Raya, totaling 5 (five) state Islamic primary schools in Palangka Raya.

\section{RESULTS AND DISCUSSION}

An increasingly competitive environment requires madrasas to be able to develop innovative, adaptive, hard-working, and caring values for others. Adaptive values are important to encourage the ability of all school/madrasah human resources to be able to win the competition (Muhaimin, Sufiah, \& Prabowo, 2015). Learners must be equipped with knowledge in a planned manner to provide them with important competencies in preparation for future education, career development, and the achievement of living well-being. For this reason, integrated teaching and learning are necessary (Fitria, 2014). The importance of the position of Islamic primary school educational institutions as one of the elements in it makes the teacher's role becomes important. 
Basic education is a basic right of citizens guaranteed by the government. The fulfillment of these rights must be prepared and implemented as well as possible. Basic education must of course be carried out and prepared as well as possible to obtain good results, and supported by human resources such as qualified and professional teachers as well. The National Medium-Term Development Plan (RPJMN) 2010-2014 and related to the RPJP 2005-2015, namely increasing Indonesia's development in all fields with the main focus on improving the quality of human resources (HR). Related to this, the teaching profession certainly has a role in improving the quality or quality of individuals with various efforts made. This study will conduct direct observations with principals and teachers at Islamic primary schools to dig up related information to elaborate on all matters relating to the problems contained in this study.

We must appreciate the efforts of the state to improve the quality of teachers, such efforts as improving education services and the successful implementation of the 2013 curriculum with programs to increase the soft skills and hard skills of students. In addition, the State also implements inclusive education in all education channels, both formal, non-formal, and informal so that education for all and gender justice can be carried out optimally.

Obtaining information related to the prospects of PGMI graduates in Palangka Raya is considered very important so that graduates of PGMI IAIN Palangka Raya get an idea after graduating from the PGMI IAIN Palangka Raya Study Program, they will have great job opportunities. In addition, this research is also important because the PGMI IAIN Palangka Raya Study Program is a study program that was just born in 2015 and has not yet graduated bachelor's degree. Government Regulation No. 19 of 2005 article 28 paragraph (1) states that educators must have academic qualifications and competencies and strive to realize national education goals. What is meant by academic qualification is the minimum education that must have been achieved by educators who have or are proven by the existence of a diploma or certificate.

However, increasing teacher education qualifications, in this case, basic education teachers at Islamic primary school and elementary school, does not necessarily require that at least a bachelor's degree is required. At first, Islamic primary school or elementary school teachers could be filled by SPG graduates, then D II, and then bachelors. If we examine based on the historical side, the enhancement of teacher qualification improvement process was SPG graduates which stands for Teacher Education Schools at the high school or vocational high school level. Graduates from this level of education can become teachers. Then with the issuance of the Decree of the Minister of Education and Culture Number 0854/O/1989 On December 30, 1989, it was determined that the qualification of elementary school teachers from SPG graduates to at least D-II PGSD graduates was stipulated. This encourages the opening of diploma II programs in the field of education such as PGMI to meet these qualifications in addition to other educational bachelor-producing study programs at PTKIN.

Along with the problems and challenges faced by the world of education which demands an increase in quality and improvement in the implementation of education in Indonesia, so the government makes the regulation in the world of education. The regulation provides various demands. This demand for increasing educational qualifications must be responded to by teachers with various actions. One of them is by increasing his competence, one of which is with a spirit of learning that never slackens and increasing his educational qualifications from the original diploma II to a minimum of a bachelor's degree in education in related fields or on his duties as a teacher.

Islamic primary school as one of the basic education levels certainly has a minimum standard in carrying out its functions. Professional teachers will become qualified teachers because in carrying out their duties and functions they will have the ability to master the material and carry out their duties well. The professionalism of teachers will certainly be very 
different for each of these teachers. As in the regulations, namely PP No. 19 of 2005 concerning National Education Standards which states about academic requirements such as educational background, it is also stated that the educational background or degree obtained when graduating from higher education is with an educational program that is under the subject being taught.

Professional abilities as teachers and teacher educators include mastery of the complete figure of teacher competence and the ability to carry out tasks that prioritize the benefit and satisfaction of students. (Wardani, 2012, p. 21). Based on the data released by the Ministry of National Education, it was stated that out of 873,650 teachers, it turned out that there was no compatibility between their diplomas and the subjects they taught in class. The presentation of the numbers and findings above is information that nationally there are quite large numbers related to the discrepancy between teachers teaching certain subjects and the educational background of teachers. PGMI as a new study program must of course also have information related to the educational background of classroom teachers who tend not or do not have a PGMI diploma background. This is important as an initial information finding so that it becomes the basis for policy for the Ministry of Religion later on.

The PGMI Study Program is certainly good news and is awaited as a business, as a policy basis, as a direction, and as an effort or strategy to prepare qualified teacher candidates who have the competence to be capable and academically skilled and professional. Of course, they are also equipped with cognitive abilities and become prospective teachers who are globally competitive. This is also supported by the knowledge of teachers to become proper educators, having the competence, and being bound by several teacher codes of ethics at the MI level. The PGMI Study Program has similarities with the PGSD Study Program in terms of curriculum, such as the existence of five compulsory subjects such as Indonesian, Mathematics, Science, Social Sciences, and Civics. But the advantage of PGMI is that it has basic subjects such as Akidah Akhlak, Fiqh, Al Quran Hadith, History of Islamic Culture, and Arabic which are the "advantages" of PGMI graduates compared to PGSD.

Regarding madrasah ibtidaiyah in Palangka Raya, both state-owned or foundationowned or private, there were 19 state Islamic primary schools and private Islamic schools. The list of the schools in Palangka Raya is as follows:
1. MIN 1
2. MIN 2
11. MIS Miftahul Jannah
3. MIN 3
12. MIS Muslimat NU
4. $\mathrm{MIN} 4$
13. MIS Nahdlatul Ulama
5. MIN 5
14. MIS Hayatul Islamiyah
6. MIS Darul Ulum
15. MIS Al Jihad
7. MIS Fathul Ulum
16. MIS Darussa'adah
8. MIS Hidayatul Insan
17. MIS Hidayatul Muhajirin
9. MIS Islamiyah
18. MIS Miftahul Huda 2
10. MIS Miftahul Huda 1
19. MIS Mutiara Insan

Teacher data at Madrasah Ibtidaiyah Negeri 1 or MIN 1 there are 41 teachers and education staff in MIN 1 consisting of 1 principal, 23 permanent teachers, 5 temporary teachers, 3 administrative staff, and 9 non-permanent employees. Then after being classified again, there are 17 homeroom teachers whose educational background is as follows, there are 14 people who have non-PGMI/PGSD backgrounds with details of 1 person having BK background and 13 having PAI background, and 3 other people being homeroom teachers or classroom teacher with PGSD background. 


\section{Educational Background}

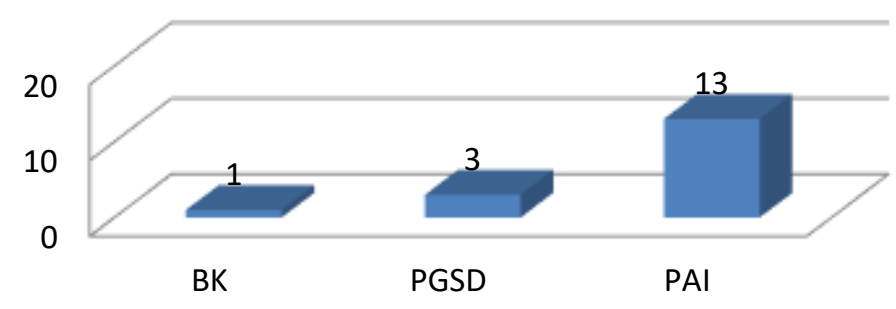

Picture 1. Educational Background of MIN 1 Teacher Education in Palangka Raya

Teacher data based on the educational background can be presented as a percentage that in MIN 1 Palangka Raya, most of the educational backgrounds are not PGMI or PGSD. The results of the data analysis show that the percentage of MIN 1 teachers who teach thematic subjects and as homeroom teachers are teachers with PAI education background is $76.47 \%$, then BK teacher education background is 5.88\%. Teachers with PGSD background have a percentage of $17.65 \%$.

At Madrasah Ibtidaiyah Negeri 2 Palangka Raya has 25 classroom teachers as well as Deputy Heads of Madrasah who teach thematically at MIN 2 Palangka Raya with details of educational background as follows: Master of Islamic Education (MPI) graduates as many as 1 (one) person, English Education 1 (one) person, and Biology Education 1 (one) person. Furthermore, there are teachers with Islamic Education post-graduate educational backgrounds. Furthermore, the educational background of Guidance Counseling teachers is 2 (two) people and the second most educational background is Elementary School Teacher Education (PGSD) as many as 7 (seven) people. Islamic Education (PAI) is the educational background for 11 (eleven) teachers or classroom teachers or thematic teachers at MIN 2 Palangka Raya.

Based on the percentages made with educational background data for thematic teachers and homeroom teachers at MIN 2 Palangka Raya, the percentage data obtained are quite balanced although it cannot be said to be ideal regarding the educational background of MIN 2 Palangka Raya teachers. The data obtained are teachers with PAI educational background who teach at MIN 2 Palangka Raya at 47.83\% then PGSD 30.43\%, and other study programs accumulated by 5 different study programs amounting to $21.74 \%$ with details of 5 backgrounds. each of these different educational backgrounds is $4.35 \%$. More details related to the educational background of the MIN 2 Palangka Raya teacher can be seen in the image below:

\section{Educational Background}

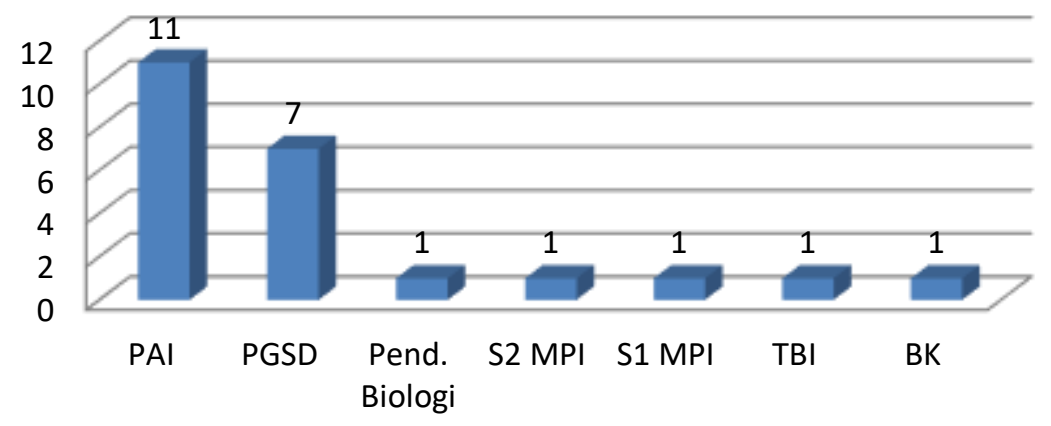

Picture 2. Educational Background of MIN 2 Teacher Education in Palangka Raya 
At Madrasah Ibtidaiyah Negeri 3 or MIN 3 through data obtained mainly through monthly report data in March 2020, data obtained that MIN 3 has 11 local classes from grade 1 to grade 6 with 11 (eleven) homeroom teachers who also teach thematically and 2 (two) class teacher. Of the thirteen thematic teachers, based on their educational background are as follows; 8 (eight) people with PAI education background, 2 (two) people with Guidance Counseling (BK) educational background, 1 (one) person with Social Sciences (IPS) education background and 2 (two) people with PGSD educational background. Of the 13 thematic teaching class teachers, 11 people have a non-PGMI or PGSD background, and only 2 people have a basic education background.

The percentage of MIN 3 teacher educational background is as follows; teachers with PAI educational background are $61.54 \%$. Then teachers with PGSD and BK educational backgrounds are both equal to $15.38 \%$ or there are two teachers each with that educational background. The other educational background is Social Studies which is one person or 7.7\% of all thematic teachers in MIN 3. The background description of thematic teachers or classroom teachers in MIN 3 can be seen in the following picture:

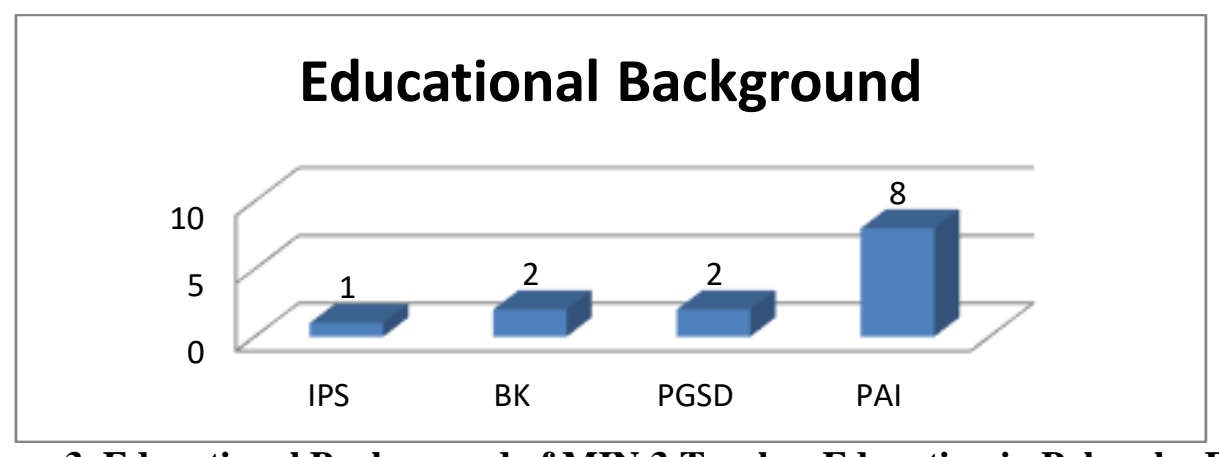

Picture 3. Educational Background of MIN 3 Teacher Education in Palangka Raya

Then, MIN 4 Palangka Raya has a description of the educational background of teachers based on data processed through the MIN monthly report, the data obtained are teachers who teach thematically or become classroom teachers with PAI educational background totaling 9 (nine) people, PGSD totaling 3 (three) people, and Economic Education totaling 1 (one) person.

If we make it into a percentage, then teachers with PAI background still dominate teachers in MIN 4 Palangka Raya with a percentage of $69.23 \%$ then teachers with PGSD background at $23.08 \%$ or as many as three people. In the last position, there is one teacher with an economic education background or a percentage of $7.69 \%$. This shows that in MIN 4 Palangka Raya, PAI is still the last education for most of the teachers in the MIN. More details related to the educational background of teachers can be seen through the following picture:

\section{Educational Background}

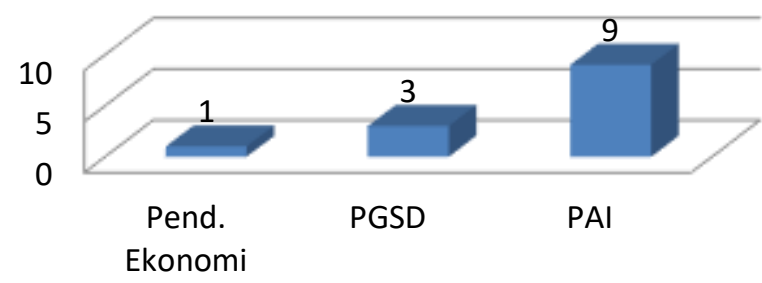

Picture 4. Educational Background of MIN 4 Teacher Education in Palangka Raya 
Furthermore, at MIN 5 Palangka Raya, the data listed in the MIN 5 monthly report was also obtained. It obtained an overview related to the educational background of teachers in thematic subjects that like other Islamic primary schools in Palangka Raya, PAI is the educational background of most teachers in MIN 5 Palangka Raya. Teachers who teach thematically have 7 (seven) PAI educational backgrounds, 3 (three) PGSD teachers and there has been Madrasah Ibtidaiyah (PGMI) teacher in MIN 5 Palangka Raya.

If written as a percentage, PAI is still the last education for most or the majority of teachers in MIN 5 Palangka Raya. Teachers with PAI educational background reached a percentage of $63.64 \%$ of all teachers in MIN 5 Palangka Raya, followed by teachers with PGSD educational background of $27.27 \%$ and PGMI of one person or $9.09 \%$. If the last education of PGSD and PGMI is combined, it will get a percentage of 36.36\%. More details can be seen through the following image:

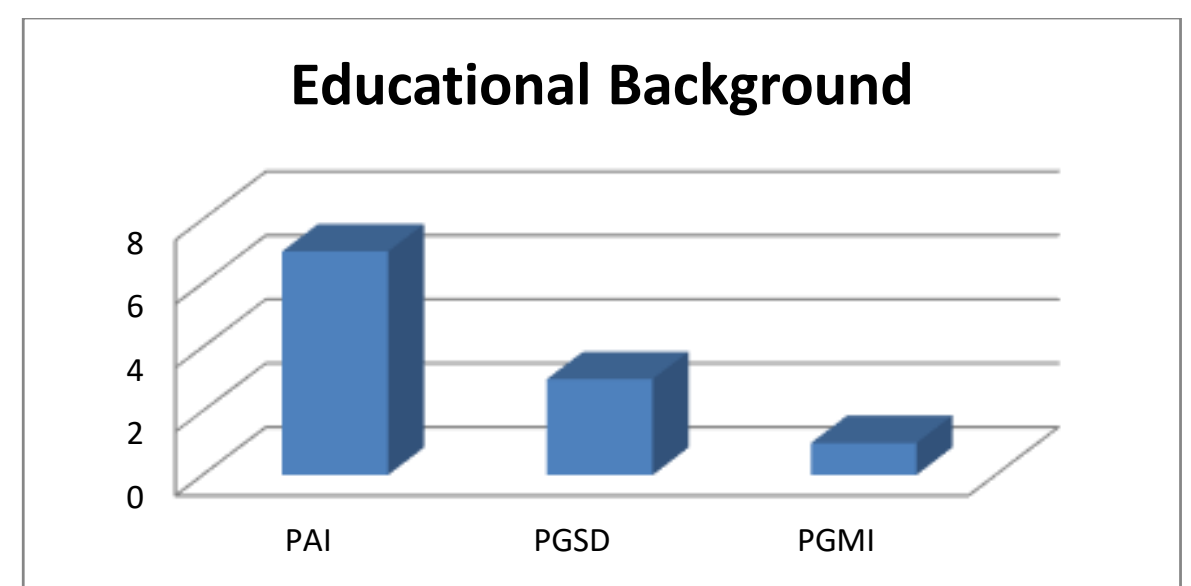

Picture 5. Educational Background of MIN 5 Teacher Education in Palangka Raya

The findings of related data certainly illustrate that the educational background of MIN class teachers is still dominated by non-PGMI graduates. As a comparison of the educational background of classroom teachers at the MIN in Palangka Raya, we can examine the data related to the educational background of teachers in one of the private MIs. The selected MIS is MIS Islamiyah Palangka Raya, and the data obtained that the educational background of teachers at the MIS is as follows; There are 5 (five) PAI teachers, 3 PGSD teachers, then other educational backgrounds, that are Sports, Social Sciences, and Science represented by 1 (one) teacher for each field. Teachers with PAI educational background have a percentage of $45.5 \%$, then PGSD is $27.2 \%$, then each educational background is represented by one teacher, Sports, Social Sciences, and Science with each percentage by $9.1 \%$. If it made in the form of an image, the educational background of teachers at Islamic primary school is as follows:

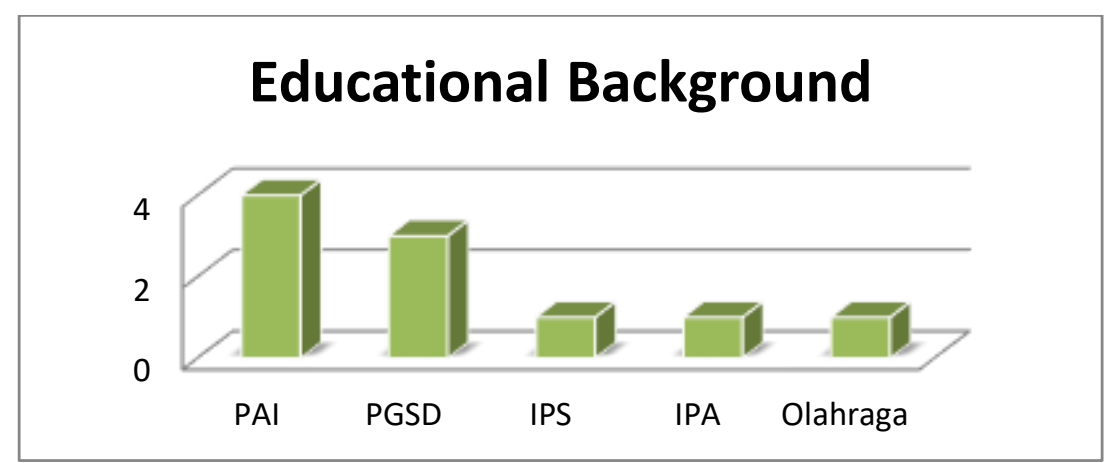

Figure 6. Background of Teacher Education at Islamic Primary School in Palangka Raya 
The position of Islamic primary school is certainly very important and recognized. This is after the juridical aspect through Law no. 20 of 2003 which states that good Islamic school ranging from ibtidaiyah, tsanawiyah, and aliyah are referred to as one of the formal educational institutions whose position has been recognized and is equal to other formal educational institutions. The National Education System Law states how the position and recognition of Islamic primary schools are. This is certainly a momentum so that Islamic primary schools can carry out their obligations in learning to continue to improve the quality of implementation by continuously improving aspects of the quality and competence of educators.

If we trace the events related to this, maybe we can start when the emergence of Law no. 20 of 2003 regarding the national education system which textually mandates that certified teachers or teachers who receive professional allowances are rumored to have to study again to adjust the field of study being taught to the field of study that is certified so that there is conformity or linear or with language that is easier to call appropriate.

The problem is that education operators in Indonesia are covered by two agencies, the Ministry of Education and Culture and the Ministry of Religion. These two agencies certainly have their policies. As we all know, the PAI Study Program is usually the favorite study program and the beginning of the establishment of higher education institutions under the Ministry of Religion. This has resulted in a large number of PAI alumni teaching at educational institutions under the Ministry of Religion, and a large number are found in Islamic primary schools, where most of the classroom teachers are PAI graduates. This is of course also because the PGMI study program like PGSD under the Directorate General of Higher Education is a study program that only existed around the 2010s. This is very dilemmatic because the policies of the two agencies are certainly different in the implementation of education in their respective agencies, even though the Ministry of Education and Culture is the main agency in issuing regulations related to national education.

Regarding the linearity problem of Islamic primary school teachers, we have to look at the applicable rules or the rules that are the legal basis. Based on the Regulation of the Minister of Religion number 90 of 2013 elementary school education / Islamic primary school only has 3 (three) kinds of teachers, namely; Classroom Teachers, PAI Teachers, and Physical Education, Sports and Health Teachers (PJOK). The government's efforts so that classroom teachers have an educational background of classroom teachers in Islamic primary school to have the appropriate diplomas have been carried out through the Dual Mode System S1 program for Islamic primary school teachers with PAI certificates, but this is still not sufficient because the quota given is very limited.

\section{CONCLUSION}

This research answers several things which we can conclude as follows. The educational background of Islamic primary school teachers in Palangka Raya is dominated by teachers with PAI educational backgrounds. This research becomes important data that in all MIN Palangka Raya, almost $60 \%$ of teachers are not graduates of PGMI or PGSD. This of course must be a concern so that the selection of educators, both civil servant and contact teacher, is focused on only accepting prospective educators with PGMI or PGSD backgrounds for classroom teacher formation. This is intended to be a stakeholder commitment related to teacher qualifications that are appropriate between the background and the established formation. Furthermore, it is necessary to take quite a strategic step by continuing to increase the role of the stakeholders together to state that the PGMI Study Program is the most ideal producer of Islamic primary school teacher candidates. In addition, the role of the PGMI 
FTIK IAIN Palangka Raya Study Program is needed to further introduce the PGMI Study Program so that it can be known to the general public.

\section{REFERENCES}

Fitria, Y. (2014). Refleksi Pemetaan Pemahaman Calon Guru SD Tentang Integrated Sains Learning. Pedagogi, XIV(2), 82-87. https://doi.org/10.1534/genetics.109.107474

Kapahang, J. O., Kojo, C., \& Uhing, Y. (2014). Pendidikan, Pengalaman Kerja dan Kompetensi Pengaruhnya Terhadap Kinerja Karyawan Pada PT PLN (Persero) Wilayah Suluttenggo. EMBA, 2(No. 4), 503-513.

Kementrian Pendidikan dan Kebudayaan. (2015). Rencana Strategis Kementrian Pendidikan dan Kebudayaan 2015-2019. Jakarta.

Kementrian Pendidikan Nasional. Undang-Undang No. 14 Tahun 2005 Tentang Guru dan Dosen.

Laelasari. (2013). Upaya Menjadi Guru Yang Profesional. Edunomic, Jurnal Ilmiah Pend. Ekonomi, Volume 1 N, 152-159.

Malik, A. (2016). Evaluasi Implementasi Kurikulum 2013 Pada Mata Pelajaran Ilmu Pengetahuan Alam (IPA) di Sekolah Menengah Pertama (SMP) (Studi Kasus di SMPN 2 Cileunyi - Bandung). Retrieved from http://digilib.uinsgd.ac.id/10967/1/1. Laporan Penelitian-Adam Malik.pdf

Muhaimin, Sufiah, \& Prabowo, S. L. (2015). Manajemen Pendidikan Aplikasinya dalam Penyusunan Rencana Pengembangan Sekolah/Madrasah (Cetakan ke). Jakarta: Kencana.

Naim, N. (2009). Menjadi Guru Inspiratif: Memberdayakan dan Mengubah Jalan Hidup Siswa. Yogyakarta: Pustaka Pelajar.

Peraturan Pemerintah Republik Indonesia Nomor 19 Tahun 2005 Tentang Standar Nasional Pendidikan. , Pub. L. No. PP No. 19 Tahun 2005 Tentang Standar Nasional Pendidikan, Sekretariat Negara RI 1 (2005).

Putri, A. D. K., \& Imaniyati, N. (2017). Pengembangan Profesi Guru Dalam Meningkatkan Kinerja Guru (Professional development of teachers in improving the performance of teacher). Jurnal Pendidikan Manajemen Perkantoran, Vol. 2 No., 93-101.

Triwiyanto, T., Kusumaningrum, D. E., \& Gunawan, I. (2017). Proyeksi Ketersediaan, Kebutuhan dan Distribusi Guru Sekolah Menengah Pertama Kota Batu. Malang.

Undang-Undang Nomor 20 Tahun 2003 Tentang Sistem Pendidikan Nasional. , Pub. L. No. UU Nomor 20 Tahun 2003, Sekretariat Negara RI (2003).

Wardani, I. G. A. K. (2012). Mengembangkan Profesionalisme Pendidik Guru Kajian Konseptual dan Operasional. Jurnal Pendidikan, Volume 13, 32-44.

Warsono. (2017). Guru : Antara Pendidik, Profesi dan Aktor Sosial. The Journal of Society \& Media, Vol. 1(1).

Yamin, M. (2006). Sertifikasi Profesi Keguruan di Indonesia. Jakarta: Gaung Persada Press. 